\title{
PENGARUH INSENTIF DAN KEPUASAN KERJA TERHADAP \\ KOMITMEN ORGANISASIONAL DAN MOTIVASI KERJA KARYAWAN QNB (QATAR NATIONAL BANK) INDOMESIA AREA SURABAYA
}

\author{
I Putu Eka Wardiana ${ }^{1}$ \\ I Gd. Adnyana Sudibya ${ }^{2}$ \\ I Gede Riana $^{3}$
}

${ }^{1}$ Fakultas Ekonomi dan Bisnis Universitas Udayana, Bali - Indonesia

Email : eka_2908@yahoo.co.id

${ }^{2}$ Fakultas Ekonomi dan Bisnis Universitas Udayana, Bali - Indonesia

${ }^{3}$ Fakultas Ekonomi dan Bisnis Universitas Udayana, Bali - Indonesia

\begin{abstract}
ABSTRAK
Istilah insentif yang digunakan dalam penelitian ini adalah sejauh mana insentif dapat memotivasi anggota organisasi (karyawan) untuk mencapai tujuan organisasi (perusahaan). Tujuan dari penelitian ini adalah untuk menganalisis signifikansi pengaruh dari pemberian insentif dan kepuasan kerja terhadap komitmen organisasional dan motivasi kerja. Penelitian ini dilakukan pada karyawan dan karyawati Bank QNB Indonesia Area Surabaya. Data dikumpulkan dengan kuesioner yang disebarkan kepada seluruh karyawan dan karyawati. Data yang telah dikumpulkan dan dianalisis menggunakan analisis deskriptif dan analisis jalur. Hasil penelitian menunjukkan bahwa pemberian insentif dan kepuasan kerja memiliki pengaruh positif dan signifikan pada komitmen organisasional. Penelitian ini juga menemukan bahwa pemberian insentif dan kepuasan kerja karyawan/wati Bank QNB Indonesia Area Surabaya memiliki pengaruh positif dan signifikan pada motivasi kerja karyawan dan karyawati di Bank QNB Indonesia Area Surabaya.
\end{abstract}

Kata kunci : insentif, kepuasan kerja, komitmen organisasional dan motivasi kerja.

\begin{abstract}
Term incentive used in this study is the extent to which incentives can motivate members of the organization (employees) to achieve the goals of the organization (company). The purpose of this study was to analyze the significance of the effect of giving incentive and job satisfaction on organizational commitment and work motivation. Research was conducted on the employees of QNB Bank Indonesia Area Surabaya. Data collected by a questionnaire distributed to all employees and employee. Data have been collected and analyzed using descriptive analysis and path analysis. The results showed that giving incentive and job satisfaction has a positive and significant impact on organizational commitment. The study also found that giving incentive and job satisfaction of employees QNB Bank Indonesia Area Surabaya has a significant positive effect on employee work motivation at the Bank QNB Indonesia Area Surabaya.
\end{abstract}

Keywords : incentives, job satisfaction, organizational commitment and work motivation. 
I Pt. Eka Wardiana, I Gd. Adnyana Sudibya, dan I Gd. Riana. Pengaruh Insentif...

\section{PENDAHULUAN}

Untuk meningkatkan kepuasan kerja karyawan pihak manajemen harus mengambil kebijakan yang bertitik tolak pada faktor-faktor yang dapat berpengaruh pada kepuasan kerja karyawannya. Hasibuan (2007) menyatakan bahwa faktor-faktor penting dalam mendorong kepuasan kerja diantaranya kerja yang secara mental menantang, ganjaran yang pantas, kondisi kerja yang mendukung dan rekan kerja yang mendukung. Untuk mewujudkan kepuasan kerja tersebut diperlukan pemahaman mengenai pentingnya komitmen organisasi agar tercipta kondisi kerja yang kondusif.

Visi PT. Bank QNB Indonesia, Tbk. adalah sebelum tahun 2017 akan menjadi Bank papan atas dalam hal kinerja keuangan di Indonesia serta merupakan institusi keuangan di Indonesia yang tumbuh dan berkembang bersama para pemangku kepentingan dalam hal pemanfaatan teknologi untuk menghasilkan kenyamanan dan proses yang ringkas. Oleh karena itu nilai-nilai yang dikandung harus sejalan dengan nilai-nilai korporarasi PT. Bank QNB Indonesia, Tbk. Sejalan dengan keinginan untuk menjadi Bank pendatang baru yang terdepan dikelasnya (new comer), proses bisnis perusahaan harus ditata ulang sesuai dengan perkembangan jaman dan tuntutan nasabah. Untuk mewujudkan visi tersebut, PT. Bank QNB Indonesia, Tbk. sangat konsisten terhadap kepuasan kerja karyawan dan komitmen orgasisasional yang akhirnya berpengaruh terhadap semangat kerja karyawan. Tidak hanya itu saja, menurut Maslow (1996) pemberian insentif yang sesuai akan memberikan kepuasan kerja karyawan. Sebelum memberikan kepuasan kepada nasabah sebaiknya karyawan 
mendapatkan kepuasan dari perusahaan (Hariandja, 2005). Semua itu akan mempengaruhi motivasi kerja karyawan.

Dalam usaha meningkatkan motivasi kerja karyawan, penting diperhatikan insentif bagi karyawan. Menurut Hariandja (2005), insentif diartikan sebagai bentuk pembayaran langsung yang didasarkan atau dikaitkan langsung dengan semangat kerja dan gain sharing, yang juga dikaitkan dengan kinerja dan diartikan sebagai pembagian keuntungan bagi karyawan akibat peningkatan produktivitas atau penghematan biaya. Sistem ini merupakan bentuk lain dari upah langsung di luar gaji dan upah yang merupakan kompensasi tetap, yang disebut sistem kompensasi berdasarkan kinerja (pay for performance plan).

Para manajer dapat menggunakan insentif dan bagi hasil sebagai alat untuk memotivasi pekerja guna mencapai tujuan organisasi. Sebab ini merupakan bentuk kompensasi yang berorientasi pada hasil kerja. Walaupun insentif mungkin sudah diberikan kepada kelompok, mereka sering memberikan penghargaan terhadap individu. Penggolongan insentif menurut Rivai (2005) dapat dibedakan menjadi dua, yaitu insentif individu yang diberikan sebagai imbalan kepada usaha dan kinerja individual serta insentif kelompok yang diberikan sebagai imbalan atas usaha dan kinerja kelompok, yangmana setelah imbalan diberikan maka akan lebih banyak kerja sama yang dituntut.

Adapun jumlah karyawan/wati PT. Bank QNB Indonesia, Tbk. Area Surabaya yang terdiri dari Cabang Darmo Surabaya, Capem Stasiun Kota Surabaya, Capem Ngagel Surabaya, dan Cabang Denpasar adalah sebanyak 86 
I Pt. Eka Wardiana, I Gd. Adnyana Sudibya, dan I Gd. Riana. Pengaruh Insentif...

orang, diharapkan bahwa PT. Bank QNB Indonesia, Tbk. Area Surabaya dapat memberikan pelayanan yang maksimal terhadap para pelanggannya.

Sumber daya manusia adalah asset penting yang harus dimiliki oleh suatu perusahaan. Menurut Utama (2001) menyatakan bahwa sumber daya manusia merupakan harta yang paling penting dan berharga yang harus dimiliki dalam suatu organisasi ditentukan oleh unsur manusia. Manusia berperan sebagai perencana, pelaksana dan sekaligus pengendali terwujudnya suatu organisasi. Dapat dikatakan sumber daya manusia merupakan aset utama, maka sudah selayaknya karyawan diperlakukan secara layak dan adil sehingga mereka dapat melaksanakan tugas dengan sungguh-sungguh dan penuh tanggung jawab serta memiliki disiplin yang tinggi untuk mencapai kinerja yang tinggi pula.

Sebagai perusahaan yang bergerak di bidang perbankan, PT. Bank QNB Indonesia, Tbk. dalam upayanya mewujudkan visi dan misi serta sebagai bank yang memiliki standar pelayanan dengan kualitas yang baik tentu mempunyai berbagai pekerjaan yang membutuhkan keterampilan (skill) bagi karyawannya dan kerja sama tim juga sangat membantu. Kedua hal ini belum cukup jika insan PT. Bank QNB Indonesia, Tbk. tidak memiliki sikap mental (attitude) yang baik. Masalahnya adalah apakah cukup hanya peningkatan kompetensi tanpa disertai dengan peningkatan dalam insentif dan kepuasan kerja serta komitmen organisasional yang tepat untuk meningkatkan motivasi kerja karyawan guna mendukung kualitas pelayanan yang lebih baik.

Kegiatan karyawan PT. Bank QNB Indonesia, Tbk. sebagian besar secara langsung berhubungan dengan nasabah, maka sudah selayaknya karyawan 
memberikan pelayanan yang terbaik kepada nasabah. Beberapa keluhan yang seringkali terjadi, diantaranya adalah pelayanan yang lebih cepat kepada nasabah yang kenal baik terhadap karyawan atau pimpinan, beberapa karyawan yang cerewet dalam memberi pelayanan, antrean yang panjang sehingga nasabah harus lama menunggu. Banyaknya keluhan-keluhan yang terjadi dapat berimbas pada menurunnya jumlah nasabah sehingga hal ini harus segera diantisipasi oleh pihak manajemen PT. Bank QNB Indonesia, Tbk. dengan memperbaiki kualitas pelayanan sehingga meningkatkan kepuasan nasabah. Hal ini dapat dikatakan sebagai indikasi rendahnya motivasi kerja karyawan PT. Bank QNB Indonesia, Tbk. sehingga pelayanan yang diberikan kepada nasabah kurang optimal.

Penelitian awal dilakukan terhadap seluruh karyawan/wati di PT. Bank QNB Indonesia, Tbk. Kantor Cabang Denpasar sebanyak 20 orang dan menanyakan apakah mereka sudah puas dengan insentif yang diberikan oleh perusahaan. Hasilnya adalah sebagian besar menyatakan masih belum merasa puas dan ingin agar nilai insentif bisa lebih ditingkatkan sehingga motivasi kerjanya bisa lebih ditingkatkan pula.

Berdasarkan uraian diatas, dapat diketahui bahwa motivasi kerja karyawan masih belum maksimal dikarenakan nilai insentif yang belum maksimal, yang mengakibatkan kepuasan dan komitmen karyawan juga belum maksimal. Oleh karenanya, PT. Bank QNB Indonesia Tbk. Area Surabaya yang mewilayahi Cabang Denpasar, disamping Cabang Darmo Surabaya, Cabang Pembantu Stasiun Kota Surabaya, Cabang Pembantu Ngagel, dan Cabang Pembantu Pasuruan sangat layak untuk dijadikan lokasi penelitian untuk mengetahui pengaruh insentif dan 
I Pt. Eka Wardiana, I Gd. Adnyana Sudibya, dan I Gd. Riana. Pengaruh Insentif...

kepuasan kerja terhadap komitmen organisasional dan motivasi kerja.Sektor pariwisata di Bali berkembang dengan pesat. Bali merupakan daerah tujuan wisata yang terkenal di dunia, yang sekaligus menjadi salah satu potensi utama untuk mengangkat citra Indonesia di mata internasional.

\section{KAJIAN PUSTAKA}

Suatu perusahaan terletak pada sumber daya manusianya. Di dalam usaha kebutuhan sumber daya manusia yang cerdas dan terampil merupakan tuntutan yang harus dipenuhi, dengan sumber daya manusia yang berkualitas diharapkan dapat membawa perusahaan ke arah kemajuan dan kesuksesan.

Untuk memenuhi tujuan tersebut maka perusahaan harus meningkatkan insentif karyawan sehingga komitmen organisasional yang dimiliki karyawan juga akan semakin baik.

Hofmans (2012) melakukan penelitian untuk melihat perbedaan individu terhadap hubungan antara kepuasan terhadap insentif dalam pekerjaan dengan kepuasan kerja itu sendiri. Analisis regresi cluster-wise terhadap tiga sampel secara konsisten menunjukkan bahwa terdapat dua tipe individu yang dibedakan menurut hubungan antara kepuasan insentif di pekerjaan dengan kepuasan kerja itu sendiri. Kelompok tipe orang pertama mengemukakan bahwa kepuasan kerja terkait dengan kepuasan terhadap insentif baik berupa insentif uang maupun insentif secara psikologis, sedangkan tipe orang kedua menunjukkan bahwa kepuasan kerja ditentukan oleh kepuasan terhadap insentif psikologis di pekerjaan. Hal ini juga terkait dengan perkembangan perusahaan kedepan dimana 
intensi turnover dan komitmen organisasional tidak hanya ditentukan oleh kepuasan terhadap insentif secara finansial tetapi juga insentif secara psikologis.

Sesungguhnya antara insentif dengan motivasi kerja karyawan terdapat hubungan yang sangat erat, dimana insentif dikatakan dapat membuat motivasi kerja karyawan akan meningkat. Sejalan dengan Zenah (2014) yang dengan responden perawat ruang rawat inap kelas III RSUD I.A Moeis Samarinda bahwa terdapat hubungan positif antara pemberian insentif dengan motivasi kerja perawat tersebut.

Mengingat insentif merupakan suatu penghasilan yang diterima karyawan selain gaji, manajemen organisasi dapat menggunakan insentif untuk meningkatkan motivasi kerja karyawan sehingga tujuan organisasi bisa tercapai. Hal ini disebabkan karena insentif merupakan bentuk kompensasi yang berorientasi pada hasil kerja. Siagian (2013) menyatakan bahwa pemberian insentif tidak saja memberikan pengaruh terhadap iklim kerja organisasi, tetapi juga memberikan efek positif terhadap peningkatan motivasi kerja karyawan.

Untuk dapat meningkatkan komitmen organisasional karyawan maka suatu organisasi harus mampu memenuhi dan meningkatkan kepuasan kerja para karyawannya. Ini berarti semakin tinggi tingkat kepuasan kerja karyawan maka semakin tinggi pula tingkat keterikatan karyawan pada suatu organisasi.

Luthans (2006) menyatakan bahwa benar kepuasan kerja merupakan hasil dari komitmen organisasional dan dari hasil riset terbaru menyimpulkan bahwa kepuasan kerja mempunyai hubungan yang positif terhadap komitmen organisasional. Sijabat (2011) juga menyatakan bahwa kepuasan kerja 
I Pt. Eka Wardiana, I Gd. Adnyana Sudibya, dan I Gd. Riana. Pengaruh Insentif...

berhubungan secara langsung maupun tidak langsung dengan intensi untuk keluar dari pekerjaan dan komitmen terhadap organisasi yang dimiliki oleh individu. Asumsi ini didasarkan pada logika bahwa jika karyawan merasa lebih dipuaskan atas pekerjaan mereka maka mereka akan lebih mungin mengembangkan komitmen yang lebih kuat kepada organisasi.

Mukhyi dan Sunarti (2007) meneliti hubungan antara kepuasan kerja dengan komitmen dalam lingkungan institusi pendidikan di kota Depok. Variabel penelitian ini terdiri dari kepuasan kerja sebagai variabel independent dan komitmen organisasi sebagai variabel dependent. Hasil penelitian disimpulkan bahwa ada hubungan yang signifikan antar kepuasan kerja dengan komitmen dalam bekerja.

Kepuasan kerja adalah salah satu faktor yang mempengaruhi semangat kerja karyawan. Jika karyawan tersebut dalam persepsinya merasakan kepuasan kerja pada perusahaan tempatnya bekerja maka karyawan tersebut akan bekerja lebih giat dan baik dengan motivasi kerja yang lebih tinggi.

Mengenai hubungan antara kepuasan kerja dan motivasi kerja karyawan, Hasibuan (2007) menyatakan bahwa : kepuasan kerja dalam pekerjaan adalah kepuasan kerja yang dinikmati dalam pekerjaan yang memperoleh pujian hasil kerja, penempatan, perlakuan, peralatan dan suasana kerja yang baik. Karyawan lebih suka menikmati kepuasan kerja dalam pekerjaan yang lebih mengutamakan pekerjaan dari pada balas jasa walaupun balas jasa itu penting.

Selain peryataan Hasibuan (2007), Handoko (2009) juga menyatakan bahwa karyawan yang mendapatkan kepuasan kerja biasanya mempunyai catatan 
kehadiran dan perputaran yang lebih baik, kurang aktif dalam kegiatan serikat karyawan dan bermotivasi kerja lebih baik daripada karyawan yang tidak memperoleh kepuasan kerja. Taurisa dan Ratnawati (2012) menyatakan dalam penelitiannya bahwa kepuasan kerja berpengaruh positif dan signifikan terhadap motivasi kerja yang nantinya akan berdampak signifikan terhadap kinerja karyawan. Jadi kepuasan kerja berpengaruh positif terhadap motivasi kerja karyawan. Karyawan yang puas dengan pekerjaannya akan lebih termotivasi dalam bekerja.

Purwanto dan Wahyuddin (2005) dalam penelitiannya tentang pengaruh faktor-faktor kepuasan kerja terhadap motivasi kerja. Faktor yang mempengaruhi kepuasan kerja adalah gaji, kepemimpinan dan sikap rekan kerja terhadap motivasi kerja dilakukan analisis mengunakan analisis regresi berganda. Faktor kepuasan kerja, gaji kepemimpinan dan sikap kerja pekerja mempunyai pengaruh signifikan dan positif terhadap motivasi kerja karyawan. Rekan kerja merupakan faktor kepuasan kerja yang mempunyai pengaruh paling dominan besar dibandingkan variabel lain terhadap motivasi kerja.

Sudiro (2008) meneliti pengaruh timbal balik antara kepuasan kerja dengan kepuasan keluarga dan komitmen kerja serta dampakanya terhadap prestasi kerja dan karier. Penelitian ini dikategorikan sebagai penelitian penjelasan yaitu penelitian yang menjelaskan hubungan kausal antara variabel-variabel melalui pengujian hipotesis. Populasi penelitian ini adalah dosen tetap yang menduduki jabatan lektor, lektor kepala, dan guru besar di Universitas Negeri di Jawa Timur yang berjumlah sebanyak 2.812 orang. Dari populasi tersebut diambil sampel 
I Pt. Eka Wardiana, I Gd. Adnyana Sudibya, dan I Gd. Riana. Pengaruh Insentif...

sebanyak 173 orang. Berdasarkan hasil analisis penelitian tersebut, disimpulkan bahwa kepuasan kerja berpengaruh kepada komitmen kerja, apabila kepuasan kerja dosen meningkat maka semakin meningkat pula komitmen kerjanya. Kepuasan kerja berpengaruh pada motivasi kerja, semakin meningkat kepuasan kerja maka semakin meningkat motivasi kerja dosen. Komitmen berpengaruh terhadap motivasi kerja, menunjukkan bahwa semakin meningkatnya komitmen kerja, semakin meningkat pula motivasi kerja dosen. Hal ini dapat dipahami bahwa komitmen kerja yang tinggi para dosen akan dapat meningkatkan motivasi kerja.

Komitmen dipandang penting dalam suatu organisasi, karena dengan komitmen yang tinggi seorang karyawan akan bersikap profesional dan menjunjung tinggi nilai-nilai yang telah disepakati bersama dalam organisasi, yang fokusnya adalah nilai-nilai dan sikap (attitude) yang dimiliki oleh karyawan. Sebagai contoh perusahaan Coca Cola, dalam menjalankan bisnisnya sangat memperhatikan komitmen dari para karyawan, karena perusahaan meyakini bahwa tanpa komitmen karyawan yang tinggi maka perusahaan tidak akan sukses. Begitu pula banyak organisasi di Jepang, utamanya organisasi bisnis, memiliki tradisi yang tumbuh berdasarkan kekuatan masyarakatnya yang mengandalkan nilai-nilai komitmen, dedikasi, loyalitas, kompetensi yang tinggi dan memiliki motivasi yang kuat untuk bekerja.

Pengembangan motivasi kerja karyawan perlu dirancang sesuai dengan visi dan misi organisasi. Disamping itu partisipasi individu secara aktif dan mandiri menjadi dinamika utamanya, sehingga kekompakan kerja dalam unit, atau 
kelompok kecil, secara intra maupun inter grup tercapai (Hadipranata, 2005). Jika karyawan berpartisipasi secara penuh dalam bekerja berarti karyawan memperhatikan kepentingan-kepentingan organisasi dalam mencapai tujuantujuannya. Karyawan menjadi lebih peduli terhadap fungsi organisasi yang efektif, sehingga lebih loyal dan berdedikasi dalam melakukan pekerjaan, serta berusaha memelihara perilaku-perilaku yang dimilikinya dalam melakukan tugas pekerjaan tersebut. Karyawan tersebut akan lebih berkomitmen dalam bekerja, karena mereka memandang usaha dan kinerja yang mereka berikan terhadap organisasi memiliki makna yang positif bagi kesejahteraan organisasi dan kesejahteraan individu mereka sendiri (Diefendorff, 2004). Sependapat dengan hal tersebut, Whitmore mengemukakan bahwa tanggung jawab dan partisipasi yang menyeluruh dapat dianggap sebagai kadar yang menunjukkan sejauh mana komitmen organisasi secara keseluruhan merupakan bagian penting dalam kehidupannya. Perilaku produktif merupakan konsekuensi dari adanya suatu tanggung jawab dari karyawan untuk mencapai kinerja yang tinggi melalui caracara kerja yang efektif dan efisien (Hartanto, 2002). Hasil dari penelitian juga menunjukkan hubungan yang positif antara kepuasan kerja dengan komitmen organisasional sert hubungan yang negatif antara kepuasan kerja dengan intensi untuk keluar dari pekerjaan (Widyadmono, 2015). Hal ini menjadikan karyawan mau mengerahkan tenaga, pikiran, dan potensinya serta berpartisipasi secara penuh untuk mencapai tujuan organisasi.

Koesmono (2005). Dalam penelitiannya tentang pengaruh komitmen organisasional terhdap motivasi dan kepuasan kerja karyawan menunjukkan 
I Pt. Eka Wardiana, I Gd. Adnyana Sudibya, dan I Gd. Riana. Pengaruh Insentif...

bahwa pengaruh terbesar adalah dari motivasi terhadap kepuasan kerja yaitu 1,62 sedangkan urutan lainnya adalah komitmen organisasional terhadap motivasi sebesar 0,680 dan motivasi terhadap kinerja sebesar 0,287, komitmen organisasiona terhadap motivasi kerja sebesar 0,506 dan terhadap kepuasan kerja sebesar 0,183 dan yang terakhir adalah kepuasan terhadap motivasi kerja sebesar 0,003. Dari hasil ini nampak bahwa komitmen organisasional merupakan hal yang pokok dalam mempengaruhi motivasi kerja. Pernyataan umum bahwa seseorang akan tercapai motivasi kerjanya apabila komitmen organisasional yang ada dalam perusahaan sangat mendukung sekali dan dapat diterima oleh karyawan.

\section{METODE PENELITIAN}

Populasi dalam penelitian ini adalah karyawan/wati PT. Bank QNB Indonesia, Tbk. Area Surabaya. Menurut Djarwanto dan Subagyo (2003), apabila populasi kurang dari 100 maka lebih baik diambil semuanya sebagai sample sehingga penelitiannya merupakan penelitian populasi. Arikunto (2004) mengatakan bahwa apabila subyeknya kurang dari 100 maka sampel yang digunakan adalah seluruhnya. Berdasarkan pandangan tersebut yang menjadi populasi penelitian ini adalah keseluruhan karyawan/wati yang ada pada PT. Bank QNB Indonesia Area Surabaya yang berjumlah 82 orang.

Penelitian ini bertujuan nuntyuk menganalisis pengaruh insentif dan kepuasan kerja terhadap komitmen organisasional dan motivasi kerja karyawan. Berdasarkan pokok masalah dan hipotesis yang diajukan, secara garis besar variable-variabel dalam analisis ini dapat diidentifikasi sebagai berikut : 
(1).Variabel terikat (dependent variable) yaitu variabel yang dipengaruhi atau yang menjadi akibat adanya variabel bebas (Sugiyono, 2006). Dalam penelitian ini yang menjadi variabel terikat adalah koitmen organisasional (Y1) dan motivasi kerja karyawan (Y2). (2). Variabel bebas (independent variable) yaitu variabel yang menjadi sebab timbulnya atau berubahnya variabel terikat (Sugiyono, 2006). Dalam penelitian ini yang menjadi variabel bebas adalah insentif (X1), dan kepuasan kerja (X2).

Untuk menghindari terjadinya salah penafsiran mengenai pengertian variablevariabel yang digunakan dalam penelitian ini, maka variabel-variabel beserta indicator-indikator yang dianalisis dapat didefinisikan sebagai berikut.

\section{Insentif (X1)}

Insentif dalam penelitian ini diartikan sebagai bentuk pembayaran yang dikaitkan dengan kinerja dan program bagi hasil (gainsharing) bagi karyawan PT. Bank QNB Indonesia, Tbk. Area Surabaya akibat peningkatan produktivitas atau penghematan biaya. Indikator yang berkaitan dengan variabel insentif adalah sebagai berikut:

(1) Bonus tahunan, adalah bonus yang didapatkan karyawan sekali dalam setahun dalam jumlah besar dan menghubungkan antara bayaran dan kinerja.

(2) Insentif langsung, adalah bonus langsung yang tidak didasarkan pada rumus, kriteria kinerja khusus, atau tujuan.

(3) Insentif individu, adalah standar kinerja individu yang ditetapkan dan dikomunikasikan sebelumnya, dan penghargaan didasarkan pada output individu. 
I Pt. Eka Wardiana, I Gd. Adnyana Sudibya, dan I Gd. Riana. Pengaruh Insentif...

(4) Insentif tim, adalah menghubungkan tujuan individu dengan tujuan kelompok kerja yang pada gilirannya biasanya dihubungkan dengan tujuan-tujuan finansial.

(5) Pembagian keuntungan, adalah program yang membagikan sebagian keuntungan langsung kepada karyawan, dan menyisihkan sisanya dalam rekening yang ditentukan.

(6) Bagi hasil, adalah program yang melibatkan seluruh karyawan dalam suatu unit kerja atau perusahaan.

\section{Kepuasan Kerja (X2)}

Kepuasan Kerja adalah apa yang dirasakan oleh para karyawan karena hasil yang dikerjakan telah mencapai hasil yang efektif dan efisien sehingga mendapatkan imbalan yang setimpal dimana dalam hal ini menurut Luthans (2006) bahwa ada lima indikator yang mempengaruhi kepuasan kerja.

(1) Gaji/penghasilan (kesesuaian gaji dengan rekan kerja dan keseuaian gaji dengan pekerjaan),

(2) Pekerjaan (deskripsi tugas dan metode tugas ),

(3) Perilaku atasan (pembinaan atasan dan objektifitas atasan),

(4) Rekan kerja (hasil kerja tim dan rekan kerja dalam mendorong penyelesaian pekerjaan),

(5) Lingkungan kerja (sarana kerja dan kenyamanan lingkungan kerja). 


\section{Komitmen Organisasional (Y1)}

Komitmen organisasional adalah ketersediaan karyawan untuk setia bekerja dan adanya keinginan untuk memajukan perusahaan dengan beberapa indikator menurut Allen dan Meyer (2003) adalah sebagai berikut.

(1) Komitmen Afektif.

(2) Komitmen Kontinuan.

(3) Komitmen Normatif.

\section{Motivasi Kerja (Y2)}

Dalam penelitian ini, yang dimaksud dengan Motivasi Kerja Karyawan adalah sikap mental dari karyawan PT. Bank QNB Indonesia, Tbk. Area Surabaya yang mampu menciptakan iklim atau suasana pekerjaan yang mendorong mereka untuk bekerja sama, bekerja lebih giat dan lebih baik, sehingga dapat memperkecil kekeliruan-kekeliruan serta dapat menyelesaikan tugas yang tepat pada waktunya. Variabel motivasi kerja karyawan diukur dengan 4 item indikator yang menggunakan skala pengukuran yaitu skala likert 4 point sangat tidak setuju (STS), tidak setuju (TS), setuju (ST), sangat setuju (SS), yang terdiri : motivasi reward, motivasi punishment, motivasi komunikasi, motivasi wewenang dan motivasi berprestasi yang diukur dari skala sangat setuju sampai skala sangat tidak setuju. Persepsi tentang motivasi kerja karyawan tersebut diukur berdasarkan indikator-indikator sebagai berikut.

(1) Absensi rendah, adalah ketidakhadiran karyawan PT. Bank QNB Indonesia, Tbk. Area Surabaya dalam tugasnya. Hal ini termasuk waktu yang hilang karena sakit, kecelakaan atau kepentingan-kepentingan pribadi. 
I Pt. Eka Wardiana, I Gd. Adnyana Sudibya, dan I Gd. Riana. Pengaruh Insentif...

(2) Kerja sama yang harmonis, adalah tindakan bersama-sama antara karyawan PT. Bank QNB Indonesia, Tbk. Area Surabaya dengan karyawan lain dimana setiap orang bekerja menyumbangkan tenaganya secara suka rela dan sadar untuk saling membantu guna mencapai tujuan bersama.

(3) Kepuasan, adalah sikap karyawan PT. Bank QNB Indonesia, Tbk. Area Surabaya yang menunjukkan tingkat kepuasan karyawan terhadap tugasnya, tingkat kepuasan terhadap lingkungan kerjanya, tingkat kepuasan karyawan terhadap jaminan yang diberikan.

(4) Disiplin, adalah ketaatan setiap karyawan PT. Bank QNB Indonesia, Tbk. Area Surabaya akan tata tertib yang berlaku dalam perusahaan tersebut, meliputi kepatuhan akan jam kerja, tata tertib yang berlaku, pakaian seragam dan sebagainya.

\section{HASIL DAN PEMBAHASAN}

Hasil pengujian hipotesis menunjukkan bahwa insentif berpengaruh positif dan signifikan terhadap komitmen organisasional. Hasil ini memberi makna bahwa semakin baik kebijakan insentif yang dilakukan, maka mampu meningkatkan komitmen organisasional karyawan dalam melaksanakan tugas dan pekerjaan. Selain itu juga, hasil penelitian ini memberikan petunjuk bahwa peran insentif yang diberikan selama ini di Bank QNB Indonesia telah terlaksana dengan baik, dan mengarah pada orientasi pada tugas. Sesuai dengan peran insentif tersebut karyawan merasa puas atas perlakuan, penghargaan, dan pengakuan terhadap kontribusi yang diberikan selama ini dalam bekerja.Temuan ini dapat 
diartikan bahwa insentif yang menarik dalam melaksanakan pekerjaan mampu memberikan kontribusi signifikan terhadap peningkatan komitmen organisasional karyawan. Dengan demikian skema insentif yang berkonsentrasi pada fungsi fungsi yang berorientasi pada tugas serta diberikan dengan sistem yang baik dan transparan, terbukti mampu memberikan rasa keberhasilan, puas dengan pekerjaan, dan melakukan sesuatu yang berharga dalam pekerjaan sehingga mereka merasa lebih puas terhadap organisasi. Hasil penelitian ini konsisten dengan hasil-hasil penelitian terdahulu, seperti: Ester (2010); Hofmans (2012); dan Kusuma (2015) yang telah menemukan bahwa pemberian insentif mampu meningkatkan komitmen organisasional karyawan. Berdasarkan pemaparan di atas maka dapat ditegaskan bahwa insentif memiliki peranan dalam meningkatkan komitmen organisasional karyawan. Hal ini dikarenakan skema insentif di Bank QNB Indonesia yang sudah cukup baik dan transparan sehingga mampu mengakomodir dan mengkoordinir dengan tantangan, tuntutan dan kebutuhan para karyawan dalam melaksanakan tugas dan pekerjaannya, sehingga nantinya akan tercipta keharmonisan dan kepatuhan karyawan terhadap aturan yang ada, serta melaksanakan perintah atau instruksi dari pimpinan.

Hasil pengujian hipotesis menunjukkan bahwa insentif berpengaruh positif dan signifikan terhadap motivasi kerja karyawan. Hasil ini memberi makna bahwa semakin baik skema insentif yang diberikan, maka dapat meningkatkan pencapaian motivasi dan hasil kerja karyawan. Temuan penelitian ini juga memberikan gambaran bahwa peran insentif yang diberikan oleh manajemen selama ini di Bank QNB Indonesia telah dilaksanakan dengan baik, serta 
I Pt. Eka Wardiana, I Gd. Adnyana Sudibya, dan I Gd. Riana. Pengaruh Insentif...

cenderung mengedepankan skema insentif yang transparan, sehingga motivasi dan pencapaian kerja karyawan dapat diraih secara optimal. Hasil penelitian ini konsisten dengan penelitian yang dilakukan Zenah (2014) dengan responden perawat ruang rawat inap kelas III RSUD I.A Moeis Samarinda bahwa terdapat hubungan positif antara pemberian insentif dengan motivasi kerja perawat tersebut. Penelitian ini selaras dengan hasil penelitian Entryana (2007); dan Praptini Yulianti (2016) yang telah menemukan bahwa insentif berpengaruh positif dan signifikan terhadap motivasi kerja. Begitu juga penelitian yang dilakukan oleh Mahyuni (2008); serta Erbasi dan Arat (2012) menemukan bahwa insentif yang berupa uang memiliki pengaruh yang lebih kuat terhadap motivasi dan kepuasan kerja. Berdasarkan pemaparan di atas maka dapat ditegaskan bahwa insentif memiliki peranan yang besar untuk mendorong peningkatan motivasi kerja karyawan. Khususnya, kesesuaian skema insentif di Bank QNB Indonesia yang menonjolkan transparansi yang jelas sehingga nantinya karyawan mampu mencapai motivasi dan hasil kerja secara baik.

Hasil pengujian hipotesis menunjukkan bahwa kepuasan kerja berpengaruh positif dan signifikan terhadap komitmen organisasional karyawan. Temuan ini memberi indikasi semakin puas pegawai bekerja, maka mampu meningkatkan capaian komitmen organisasional yang semakin baik. Hasil penelitian ini juga memberikan petunjuk bahwa karyawan yang bekerja selama ini di Bank QNB Indonesia merasa puas dengan tugas dan pekerjaan yang diberikan. Ekspresi kepuasan pegawai tersebut memberikan dampak yang positif terhadap komitmen organisasional karyawan. Temuan ini juga dapat diartikan bahwa pekerjaan yang 
memberikan rasa keberhasilan, insentif yang diterima sesuai dengan beban kerja, kemampuan organisasi dalam memberikan kesempatan untuk maju, dukungan dari atasan, dan rekan kerja yang selalu siap untuk membantu memberikan kontribusi signifikan terhadap peningkatan komitmen organisaional karyawan. Dengan memperhatikan rasa puas terhadap keberhasilan karyawan dengan segala aktivitas yang dilakukan, telah terbukti mampu mengarahkan para pegawai untuk mampu menggunakan waktu secara efektif dalam bekerja, memegang teguh profesionalisme dalam bekerja, dan melaksanakan pekerjaan sesuai dengan prosedur yang ada sehingga mereka mampu berkinerja secara lebih optimal. Hasil penelitian ini konsisten hasil penelitian Luthans (2006) yang menemukan bahwa kepuasan kerja merupakan hasil dari komitmen organisasional dan dari hasil riset terbaru menyimpulkan bahwa kepuasan kerja mempunyai hubungan yang positif terhadap komitmen organisasional. Demikian pula beberapa penelitian terdahulu yang telah menemukan pengaruh positif dan signifikan antara kepuasan kerja terhadap komitmen orgas \nisasional karyawan (Sijabat, 2011 dan Mukhyi dan Sunarti, 2007). Berdasarkan pemaparan di atas maka dapat disampaikan bahwa komitmen organisasi juga dapat ditentukan dari kepuasan kerja pegawainya. Pegawai yang puas dengan pekerjaannya cenderung akan menghasilkan efektifitas kerja yang lebih baik. Apabila karyawan mengekspresikan kepuasannya, maka karyawan tersebut juga akan berusaha semaksimal mungkin untuk menyelesaikan tugas dan tanggung jawabnya, sehingga produktivitas dan kinerjanya akan semakin meningkat. 
I Pt. Eka Wardiana, I Gd. Adnyana Sudibya, dan I Gd. Riana. Pengaruh Insentif...

Hasil pengujian hipotesis menunjukkan bahwa kepuasan kerja berpengaruh positif dan signifikan terhadap motivasi kerja. Hasil ini memberi makna bahwa semakin baik kepuasan kerja karyawan, maka mampu meningkatkan motivasi kerja karyawan dalam melaksanakan tugas dan pekerjaan. Selain itu juga, hasil penelitian ini memberikan petunjuk bahwa peran kepuasan kerja yang baik akan memberikan motivasi kerja yang baik pula yang orientasi pada tugas. Temuan ini dapat diartikan bahwa kepuasan kerja yang baik dalam melaksanakan pekerjaan mampu memberikan kontribusi signifikan terhadap peningkatan motivasi kerja karyawan. Dengan demikian kepuasan kerja terbukti mampu memberikan motivasi kerja yang semakin baik dalam melaksanakan kegiatan dan bekerja sesuai tugas dan tanggung jawab masing-masing. Hasil penelitian ini konsisten dengan hasil-hasil penelitian terdahulu, seperti: Hasibuan (2007); Handoko (2009); Taurisa dan Ratnawati (2012) yang telah menemukan bahwa kepuasan kerja berpengaruh positif dan signifikan terhadap motivasi kerja yang nantinya akan berdampak signifikan terhadap kinerja karyawan. Demikian pula penelitian yang dilakukan oleh Sudiro (2008) menemukan hubungan yang sangat erat antara kepuasan kerja dan motivasi kerja karyawan. Berdasarkan pemaparan di atas maka dapat ditegaskan bahwa kepuasan kerja memiliki peranan yang signifikan dalam meningkatkan motivasi kerja karyawan. Hal ini dikarenakan kepuasan kerja karyawan di Bank QNB Indonesia yang sudah cukup baik sehingga mampu memberikan motivasi kerja karyawan yang besar dalam melaksanakan tugas dan pekerjaannya, sehingga nantinya akan tercapai kinerja yang diinginkan perusahaan. 
Hasil pengujian hipotesis menunjukkan bahwa komitmen organisasional berpengaruh positif dan signifikan terhadap motivasi kerja karyawan. Hasil ini memberi makna bahwa semakin baik komitmen organisasional karyawan, maka dapat meningkatkan pencapaian motivasi dan hasil kerja karyawan yang baik pula. Temuan penelitian ini juga memberikan gambaran bahwa peran komitmen organisasi yang dirasakan oleh karyawan Bank QNB Indonesia telah terlaksana dengan baik, serta cenderung mengedepankan rasa loyalitas dan bangga terhadap perusahaan, sehingga motivasi dan pencapaian kerja karyawan dapat diraih secara optimal. Hasil penelitian ini konsisten dengan penelitian yang dilakukan Hadipranata (1998), bahwa pengembangan motivasi kerja karyawan perlu dirancang sesuai dengan visi dan misi organisasi. Lebih lanjut Diefendorff (2012) menyatakan melalui hasil penelitiannya bahwa karyawan akan lebih berkomitmen dalam bekerja karena mereka memandang usaha dan kinerja yang mereka berikan terhadap organisasi memiliki makna yang positif bagi kesejahteraan organisasi dan kesejahteraan individu mereka sendiri. Sejalan dengan penelitian Koemono (2005) tentang pengaruh komitmen organisasional terhadap motivasi dan kepuasan kerja. Dimana diperoleh hasil bahwa komitmen organisasional merupakan hal yang pokok dalam mempengaruhi motivasi kerja. Berdasarkan pemaparan di atas maka dapat disimpulkan bahwa komitmen organisasi juga dapat menentukan motivasi kerja karyawan. Karyawan yang mempunyai komitmen organisasional yang tinggi cenderung akan menghasilkan efektifitas kerja yang lebih baik dan lebih termotivasi dalam bekerja dibandingkan karyawan dengan komitmen organisasional rendah. 
I Pt. Eka Wardiana, I Gd. Adnyana Sudibya, dan I Gd. Riana. Pengaruh Insentif...

Tabel 1

Analisis Regresi - Struktur 1

\begin{tabular}{llllll}
\hline \multicolumn{1}{c}{ Model } & B & Std. & Beta & t & Sig. \\
& \multicolumn{5}{c}{ Error } \\
& & & & \\
\hline (Constant) & 3.087 & 0.939 & & 3.288 & 0.002 \\
Insentif & 0.536 & 0.258 & 0.252 & 2.080 & 0.041 \\
Kepuasan & 0.527 & 0.155 & 0.411 & 3.390 & 0.001 \\
$\mathrm{R}^{2}=0,373$ & & & & & \\
$\mathrm{~F}=23,547$ & & & & & \\
Sig F $=0,000$ & & & & & \\
\hline
\end{tabular}

Berdasarkan hasil analisis data pada Tabel 1 diperoleh persamaan regresi sebagai berikut : $\mathrm{Y} 1=0,252 \mathrm{X}_{1}+0,411 \mathrm{X}_{2}$

Persamaan regresi yang didapat dari Tabel 1 mememuhi uji ketepatan model karena nilai signifikansi Uji F (Anova) sebesar 0,000 lebih kecil dari 0,05. Dengan demikian variabel Insentif dan Kepuasan kerja tepat digunakan untuk mengesttimasi nilai variabel komitmen organisasional.

Variabel Insentif dengan koefisien beta positif sebesar 0,252 dan signifikansi uji t sebesar 0,041menunjukkan bahwa insentif berpengaruh positif pada komitmen organisasional. Demikaian juga variabel kepuasan kerja dengan koefisien beta sebasar 0,411 dan nilai signifikansi uji $\mathrm{t}$ sebesar 0,001 menunjukkan bahwa variabel $\mathrm{t}$ ersebut secara positif berpengaruh signifikan terhadap komitmen organisasi.

Berdasarkan hasil analisis pada Tabel 1, variabel Insentif dan Kepuasan Kerja secara positif berpengaruh terhadap Komitmen Organisasional. Namun demikian, 
ada varian variabel Komitmen Organisasional yang tidak mampu dijelaskan oleh variabel Insentif dan Kepuasan Kerja. Besarnya nilai varians tersebut disebut dengan error1 yang dapat dihitung dengan rumus berikut:

$$
\begin{aligned}
& e_{1}=\sqrt{1-R^{2}} \\
& e_{1}=\sqrt{1-0,373} \\
& e_{1}=0,79
\end{aligned}
$$

Nilai error sebesar 0,79 menunjukkan bahwa 79 persen vaians Komitmen Organisasional itu dijelaskan oleh variabel di luar Insentif dan Kepuasan Kerja.

\begin{tabular}{|c|c|c|c|c|c|}
\hline Model & B & $\begin{array}{l}\text { Std. } \\
\text { Error }\end{array}$ & Beta & $\mathbf{t}$ & Sig. \\
\hline (Constant) & -3.238 & 0.553 & & -5.857 & 0.000 \\
\hline Insentif & 0.487 & 0.146 & 0.314 & 3.332 & 0.001 \\
\hline Kepuasan & 0.351 & 0.092 & 0.376 & 3.821 & 0.000 \\
\hline Komitmen & 0.176 & 0.062 & 0.241 & 2.831 & 0.006 \\
\hline \multicolumn{6}{|l|}{$\mathrm{R}^{2}=0,645$} \\
\hline \multicolumn{6}{|l|}{$\mathrm{F}=47,220$} \\
\hline $\operatorname{Sig} F=0,000$ & & & & & \\
\hline
\end{tabular}

Tabel 2

Analisis Regresi - Struktur 2

Berdasarkan hasil analisis data pada Tabel 2 diperoleh persamaan regresi sebagai berikut:

$$
\mathrm{Y} 1=0,314 \mathrm{X}_{1}+0,376 \mathrm{X}_{2}+0,241 \mathrm{X}_{3}
$$

Persamaan regresi yang didapat dari Tabel 2 mememuhi uji ketepatan model regresi karena nilai signifikansi Uji F (Anova) sebesar 0,000 lebih kecil dari 0,05. 
I Pt. Eka Wardiana, I Gd. Adnyana Sudibya, dan I Gd. Riana. Pengaruh Insentif...

Dengan demikian variabel Insentif, Kepuasan Kerja dan Komitmen Organisasional tepat digunakan untuk mengesttimasi nilai variabel Motivasi Kerja.

Variabel Insentif dengan koefisien beta positif sebesar 0,314 dan signifikansi uji t sebesar 0,001 menunjukkan bahwa insentif berpengaruh positif pada Komitmen Organisasional. Variabel Kepuasan Kerja dengan koefisien beta sebasar 0,376 dan nilai signifikansi uji t sebesar 0,000 menunjukkan bahwa variabel kepuasan secara positif berpengaruh signifikan terhadap Motivasi Kerja. Demikian juga variabel Komitmen Organisasional dengan koefisien jalur sebesar 0,241 dan nilai signifikansi uji $\mathrm{t}$ sebesar 0,006 menunjukan bahwa variabel tersebut juga berpengaruh positif signifikan terhadap motivasi kerja.

Berdasarkan hasil analisis pada Tabel 2, variabel Insentif, Kepuasan Kerja dan Komitmen Organisasional secara positif berpengaruh terhadap Motivasi Kerja. Namun demikian, ada varian variabel Motivasi Kerja yang tidak mampu dijelaskan oleh variabel ketiga variabel tersebut. Besarnya nilai varians tersebut disebut dengan error2 yang dapat dihitung dengan rumus berikut:

$$
\begin{aligned}
& e_{2}=\sqrt{1-R^{2}} \\
& e_{2}=\sqrt{1-0,645} \\
& e_{1}=0,596
\end{aligned}
$$

Nilai error sebesar 0,596 menunjukkan bahwa 59,60 persen vaians Motivasi Kerja itu dijelaskan oleh variabel di luar Insentif, Kepuasan Kerja dan Komitmen Organisasional. 


\section{SIMPULAN DAN SARAN}

Berdasarkan analisis penelitian dan pembahasan yang telah dipaparkan maka dapat diambil kesimpulan, sebagai berikut: 1). Pemberian insentif berpengaruh positif dan signifikan terhadap komitmen organisasi karyawan Bank QNB Indonesia Area Surabaya, yang berarti bahwa semakin tinggi besaran Insentif yang diberlakukan di Bank QNB Indonesia, maka akan meningkatkan komitmen organisasi karyawan PT. Bank QNB Indonesia Area Surabaya. 2). Insentif juga berpengaruh positif dan signifikan terhadap motivasi kerja karyawan Bank QNB Indonesia Area Surabaya, yang berarti bahwa makin besar insentif yang diterima maka akan menambah motivasi kerja karyawan Bank QNB Indonesia Area Surabaya. 3). Kepuasan kerja berpengaruh positif dan signifikan terhadap komitmen organisasi karyawan Bank QNB Indonesia Area Surabaya, yang berarti bahwa semakin tinggi kepuasan kerja karyawan Bank QNB Indonesia Area Surabaya, maka semakin besar komitmen organisasi karyawan terhadap perusahaan. 4). Kepuasan kerja juga berpengaruh positif dan signifikan terhadap motivasi kerja karyawan Bank QNB Indonesia Area Surabaya, yang berarti bahwa semakin tinggi kepuasan kerja karyawan Bank QNB Indonesia Area Surabaya, akan mampu meningkatkan motivasi kerja karyawan terhadap perusahaan. 5). Komitmen orgasinasi berpengaruh positif dan signifikan terhadap motivasi kerja karyawan Bank QNB Indonesia Area Surabaya, yang berarti bahwa semakin tinggi komitmen organisasi karyawan Bank QNB Indonesia Area Surabaya, maka semakin tinggi pula motivasi kerja karyawan terhadap perusahaan. 
I Pt. Eka Wardiana, I Gd. Adnyana Sudibya, dan I Gd. Riana. Pengaruh Insentif...

Berikut ini saran-saran yang dapat dikemukakan kepada manajemen Bank QNB Indonesia: 1). Pemberian Insentif merupakan faktor penting yang mempengaruhi komitmen organisasi dan motivasi kerja karyawan Bank QNB Indonesia Area Surabaya. Dalam hal ini pemberian insentif yang dari hasil penelitian memiliki nilai yang cukup berpengaruh terhadap motivasi kerja. Hasil ini menunjukkan perlunya upaya perusahaan untuk lebih menekankan pemberian insentif yang maksimal sesuai standard perusahaan, sehingga dapat meningkatkan komitmen organisasi dan motivasi kerja karyawan yang optimal. 2). Hasil penelitian menunjukkan juga bahwa kepuasan kerja juga sangat mempengaruhi komitmen organisasi dan motivasi kerja karyawan Bank QNB Indonesia Area Surabaya sehingga program kesejahteraan karyawan dan keluarganya agar lebih ditingkatkan sehingga akan menambah motivasi kerja karyawan yang juga akan menghasilkan kinerja yang maksimal terhadap setiap karyawan Bank QNB Indonesia Area Surabaya.

\section{REFERENSI}

Allen, N.J. dan Meyer, J.P. 2003. Commitment in the Workplace : Theory, Research, and Application. Thousand Oaks, CA. : Sage Publishing, Inc.

Arikunto. 2004. Dasar-Dasar Evaluasi Pendidikan. Jakarta : Bumi Aksara.

Diefendorff, J.M., Brown, D.J., Kamin, A.M. \& Lord, R.G. 2012. Examining The Roles of Involvement and Work Centrality in Predicting Organizational Citizenship Behavior and Job Performance. Journal of Organizational Behavior. 23. 93 - 109

Entryana, Friska. 2007. Pengaruh Insentif dan Keselamatan Kerja terhadap Motivasi Kerja Karyawan Pabrik Gula Djombang. Tesis. Program Pasca Sarjana Universitas Airlangga. Surabaya. 
Hadipranata, AF. 1998. Bahan Kuliah Perencanaan Sumber Daya Manuasia. MM - UII Yogyakarta.

Handoko, Hani, T. 2009. Manajemen Personalia dan Sumber Daya Manusia. Yogyakarta : BPFE.

Harianja, Marihot Tua Efendi. 2005. Manajemen Sumber Daya Manusia, Pengadaan, Pengem-bangan, Pengkompensasian, dan Peningkatan Produktivitas Pega-wai. Jakarta: PT. Grasindo.

Hartanto. 2002. Manajemen Sumber Daya Manusia (edisi 2). Jakarta : PT. Prehallindo.

Hasibuan Malayu S.P. 2007. Manajemen Sumber Daya Manusia. Jakarta : PT. Bumi Aksara.

Hofmans Joeri, Gieter Sara De, Pepermans Roland. 2012. Individual dijjerences in the relationship between satisfaction with job rewards and job satisfaction. Journal of Vovational Behaviour. Article in Press. No. Of Page : 9; 4C.

Koesmono. 2005. Pengaruh Budaya Organisasi Terhadap Motivasi dan Kepuasan Kerja serta Kinerja Karyawan. Jurnal Manajemen dan Kewirausahaan, vol 7, no 2, September $2005: 171-188$.

Mukhyi, Mohammad Abdul dan Sunarti, Tati. 2007. Hubungan antara Kepuasan Kerja dengan Komitmen dalam Lingkungan Institusi Pendidikan di Kota Depok. Jurnal Ilmiah Universitas Gunadarma Vol.2.

Praptini Yulianti, FX Perdana. 2016. Pengaruh Sumber-Sumber Insentif Terhadap Motivasi Kerja Tenaga Edukatif Tetap Fakultas Ilmu Sosial Universitas Airlangga di Surabaya. Jurnal Manajemen Airlangga.

Purwanto \& Wahyuddin. 2005. Pengaruh Faktor-faktor Kepuasan Kerja terhadap Kinerja Karyawan Pusat Pendidikan Komputer Akuntansi IMKA di Surakarta. Jurnal Manajemen Universitas Gajah Mada.

Siagian, Sondang P. 2013. Manajemen Sumber Daya Manusia. Jakarta : Bumi Aksara.

Sijabat, J. 2011. Pengaruh Kepuasan Kerja terhadap Komitmen Organisasi dan Keinginan untuk Pindah. National Conference on Management Research.

Sudiro, Achmad. 2008. Pengaruh Kepuasan Kerja, Komitmen Kerja dan Kinerja serta Pengaruhnya terhadap Karier Dosen. National Conference on Management Research.

Sugiyono. 2006. Metode Penelitian Pendidikan (Pendekatan Kuantitatif, Kualitatif dan $R \& D$ ). Bandung : Alfabeta. 
I Pt. Eka Wardiana, I Gd. Adnyana Sudibya, dan I Gd. Riana. Pengaruh Insentif...

Taurisa, Chaterina Melina dan Ratnawati, Intan. 2012. Analisis Pengaruh Budaya Organisasi dan Kepuasan Kerja terhadap Komitmen Organisasional dalam Meningkatkan Kinerja Karyawan (Studi pada PT. Sido Muncul Kaligawe Semarang). Jurnal Bisnis dan Ekonomi (JBE), Hal. 170 - 187.

Utama, W. Mudiartha, Ni Wayan Mujiati, Komang Ardana. 2001. Manajemen Sumber Daya Manusia. Denpasar : Universitas Udayana.

Widyadmono, V. Mardi. 2015. Pengaruh Kepuasan Kerja dan Komitmen Organisasi terhadap Turnover Intention (Study pada Accounting Staff Perusahaan Swasta di DIY). Jurnal Manajemen Indonesia Vol. 15 - No. 2 hal. $157-167$.

Zenah, Syarifah Nur. 2014. Hubungan Pemberian Insentif dengan Motivasi Kerja Perawat Ruang Rawat Inap Kelas III RSUD Inche Abdul Moeis Samarinda. eJournal Administrasi Negara. 